\title{
The situation of poultry industry and related veterinary service in republic of Yemen, 2007
}

\author{
G. A. Zohair \\ Department of animal production, Faculty of Agriculture, Sana'a University, Republic of Yemen.
}

The purpose of the assignment is to provide technical assistance to support the preparation /strengthening of the currently drafted Integrated National Planning for disease prevention, requirement from poultry products and required improvements for future. The obtained data here were collected from site visits and interviews with project owner as well as official documents and reports.

\section{The Poultry Industry.}

\subsection{Sector Profile.}

The Yemeni poultry sector represents one of the largest livestock sector investments in the country, with an estimated investment of over US\$2 billion. Poultry production contributes $70 \%$ of total national livestock production value and has increased rapidly during the last decade, increasing at an average rate of about $7 \% /$ year. This growth rate is driven by increasing disposable income and a demand for affordable poultry meat, the country's principal staple meat, comprising about $63 \%$ of total national meat production. Current poultry meat production only covers $52 \%$ of domestic demand, however, with the balance imported as frozen meat, mostly from South American suppliers.

The industry is divided into 4 Sectors $^{1}$ (Table 1 and 2), each with its own production scale and husbandry standards. Sectors 1 and 2 farms are Parent stock (P-stock) farms, providing layer pullets and day-old chicks (DOC) to commercial layer and broiler farmers. The country is only $50 \%$ self-sufficient in DOC and has to import the balance by airfreight from OIE-accredited HPAIfree countries, licensed and monitored by the Ministry of Agriculture and Irrigation (MoAI) Directorate General of Animal Resources (DGAR). Grand Parent (GP) farms in overseas countries provide genetic replacement stock for P-stock farms by air freighting day-old chicks or breeding eggs, to provide P-stock farms with replacement stock to generate commercial starter poultry for the industry ${ }^{2}$.

* Corresponding author.

E-mail address: gzohair@gmail.com

(Ghazi Ali M. Zohair)
The country has a standing poultry population ${ }^{3}$ of 36.7 million, comprised of $90 \%$ commercial 21.8 million), confined poultry and $10 \%$ freeranging (9 million) backyard poultry. These birds are kept on some 3,300 poultry farms (Sectors 1, 2 and 3), with 200,000 households raising Sector 4 free0ranging backyard poultry in small flocks averaging 45 birds per household.

Virtually all commercial poultry farms are located along a north-south zone across the highlands, starting from the southern uplands of Taiz and Ibb Governorates, with the majority of P-stock farms in the central highlands of Ibb (Yarim), Albayeda, Dhamar and Sana'a, with the majority of broiler and layer farms located in the northern highlands of Amran, parts of Hajjah, Sana'a and Sa'dah Governorates (Fig 1) Most of the country's 15 hatcheries are located in the humid, hotter coastal lowlands of the Tihamah Zone, where the humid, warm climate provides a conducive environment for hatching.

\subsection{Average Broilers breeding Costs.}

The batch of 10,000 day-old chicks, farm local breeder, costs $\$ 4,000$; Feed and other production necessities cost about $\$ 24,000$ per batch.

\subsection{Broiler farms Biosafety.}

Poultry farms in the Al Hatarish District of Sana'a Governorate; a heavily populated area, with shops and roadside fruit and dry-goods markets lining the road. On either sides, the low-slung corrugated metal roofs of poultry shed glint in the sun. A

\footnotetext{
${ }^{1}$ FAO poultry industry categorization by Sector

${ }^{3}$ To avoid inbreeding with resulting production drops, $\mathrm{P}$ breeding stock has a turnover rate of 1 year only.

${ }^{3}$ Standing poultry population - the number of poultry taken at a snapshot. Poultry inventory - the number of poultry produced in the time span of 1 year.
} 
poultry truck is parked aside, loading broilers. There are no footbaths anywhere, poultry and feed trucks enter and leave the compound at will, as do visitors .

\section{Poultry Marketing and Processing.}

The poultry marketing chain is an important infrastructure in either promoting or breaking infectious poultry diseases. The marketing of poultry products in Yemen is governed by the consumer habit of selecting live poultry at the market and have these halal-slaughtered at the time of purchase. In spite of this habit, dressed, frozen poultry is imported from Brazil for the hotel and restaurant trade in the larger cities. The poultry market chain begins with middlemen who purchase broilers and table eggs directly from the producer and transport these in woven or plastic cages, and in carton-packed egg trays, to the city and town markets. Individual producers will sometimes market their poultry directly to these markets without an intermediary. From the wholesale markets, and occasionally directly from the farms, broilers and eggs are distributed by a second tier of middlemen to city poultry shops or to smaller village markets. Poultry slaughtering is therefore decentralized, making consumer biosafety and hygienic poultry handling a difficult task. For example, Sana'a City has one new wholesale market supplying about 340 poultry shops in the city, with a daily turnover sales some 100,000 chickens. In the villages, households purchase live poultry from their local markets or take them from their own flocks, and slaughter these at home. The constant intermingling of middlemen, poultry and water trucks, poultry and egg transport crates between farms, live-bird markets, poultry shops and consumers, with scant attention paid to biosecurity and hygienic poultry handling, presents a formidable challenge in trying to break virus infection chains. Poultry slaughtering and marketing responsibilities were transferred from DGAR to the General Corporation of Slaughterhouses and Meat Markets under the Ministry of Municipalities, currently renamed the Ministry of Public Works and Roads. This institutional disconnect will be rectified by returning poultry processing and marketing oversight to DGAR. The 2004 Organization and Protection of Livestock Law No 17 gives MoAI (and thereby DGAR) the responsibility to control meat inspection and livestock markets, and needs to be adjusted to give DGAR the authority to control slaughtering and market hygiene standards. This regulatory matter must be resolved at the earliest possible opportunity to allow MoAI to exert effective control over poultry markets and movement bans, in case of disease outbreaks.

\section{Migratory Bird Flyways.}

Yemen is located directly under two major migratory bird flyways (fig2), a matter of considerable concern to veterinary authorities, who view the potential danger of new emerging disease entry from wild bird species that rest in coastal areas as a significant potential route of infection. Birds migrating along the Black Sea Flyway originate from northern Siberia and Scandinavia and cross the mid sections of the country to the Red Sea coast, where they rest in habitats on the cluster of off-shore islands adjacent to Hajjah and $\mathrm{Al}$ Hudaydah Governorates, both heavily populated with commercial farms, on their way to the wetlands and watersheds of the Rift Valley in East Africa. Birds migrating along the East AfricaWest Asia Flyway originate from Central Asia and rest in the coastal lowlands of the Gulf of Aden, an area well away from domestic poultry populations. Some 120 wild bird species have been identified along the coastal zones of Yemen, including members of the Anseridae Family (ducks, geese and swans) which are known to be HPAI virus carriers. With the exception of coastal hatcheries, which practice high levels of biosecurity, the coastal lowlands of Yemen contain no commercial poultry farms and only small, scattered flocks of free-ranging backyard poultry. Plans for depopulating the coastal areas of backyard poultry have been described to remove the potential of wild bird- domestic poultry crossover infection. Although the potential of virus transfer from migratory birds to domestic poultry must be seen as a potential threat, the chances of precipitating major outbreaks from this source are considered slim, given the very low human and poultry densities in these migratory areas and the relatively greater threats via other routes of infection, such as legal and illegal overland entry, the importation of dayold chicks and generally weak poultry farm biosecurity Nevertheless, migratory bird surveillance of these coastal areas is warranted (and being carried out) to monitor unusual wild bird and/or domestic poultry die offs.

\section{Veterinary and Laboratory Services.}




\subsection{Governmental.}

\subsubsection{Laboratory Services.}

The Central Veterinary Laboratory (CVL) in Sana'a City is over 35 years old with much of its major equipment and facilities outdated and beyond repair. The IAEA, through various TCPs, in the past has provided equipment, technical assistance and training to improve diagnostic capability, but no recent donor support has been forthcoming. FAO has also supported the CVL with training in HPAI-dedicated diagnostics and the procurement of laboratory antigens and consumables.

There are four regional veterinary laboratories in Al Hodaydah , Taiz, Jo'ar (Abyen Governorate) and Marib. These laboratories require upgrading in staff and diagnostic skills.

4.1.2: Yemen Veterinary Society.

This professional group counts 187 members of the country's 230 veterinarians and was established as recently as 2005. Government veterinary members count 72 , and 40 members work in the poultry industry (which comprises 5,300 farms). A serious shortage of veterinarian exists in Hajjah, Al Mahwit, Sana'a, Amran and Shabwah Governorates. This shortage is especially problematic in Sana'a and Amran, home to 35\% of the national poultry flock, where effective disease surveillance is compromised. Over the longer term, veterinary work force will shrink as no new government veterinarians have been hired since 1991 and many will reach retirement age in 10 years time. The new veterinary faculty will begin graduating some 15 veterinarians per year in two years time, but will not be able to meet the manpower attrition (Table 3).

\subsection{Private Sector.}

\subsubsection{Civil Society Organizations.}

Only limited collaboration exists between public and private sector agencies responsible for poultry health, marketing and processing. The Yemen Veterinary Medical Association (YVMA) was formed in 1997 and almost all veterinarians, 185 of a total of 200 from the public as well as private sectors, are members. The YVMA played an important role during the 2001/02 Rift Valley Fever outbreaks when it organized and coordinated the public and private sector surveillance and control response against this disease, and would do so again should avian flu strike the country. The General Poultry
Association of Poultry Producers and Marketers, under the umbrella of the Agriculture Cooperative Union, represents private sector poultry producers and marketers with Government. The Association of Consumer Protection, headed by the GD General Authority of Standards and Measurements, exerts quality control over animal food standards, such as imported frozen chicken. However, there is little formal operational collaboration between these agencies.

On the private sector side, many Sector 1 and 2 breeder and commercial poultry farms have in-house veterinary staff, but the majority of lower-level Sector 2 and 3 farms do not. These farms are also must prone to virus infection due to a lack of basic biosecurity. A general lack of knowledge by livestock farmers of preventive care hampers general livestock (and poultry) production efficiency. Surveillance beyond the district level relies mostly on farmer reports of animal disease remains the main mode of MoAI access to information.

5. Animal Quarantine and Movement Controls. Yemen's geographical location lies at the crossroads of several animal trading routes between Africa and the Arabic Peninsula, especially for ruminant livestock. Human health and veterinary legislation in Yemen stipulates that all imported livestock must be held on arrival for quarantine inspection. However, regulatory enforcement presents difficulties due to inadequate facilities and trained manpower at air, land and seaport entry points. The DGAR, responsible for animal quarantine, supervises quarantine points for the export and import of live animals and animal products. The Mocha Quarantine Station on the Red Sea border with Saudi Arabia is the main point of entry for all livestock species, with the Mukalla quarantine station on the Arabian Sea the second largest entry point. Additional checkpoints are located at the north-west border with Saudi Arabia, a significant entry point for day-old chicks. Others include the Hoaf checkpoint on the eastern boarder with Oman; Sana'a Airport (vaccines, drugs, hatching eggs, day-old chicks), and the Al Hodaydah and Aden Seaport check points. For the purposes of securing borders against the entry of avian influenza, the Sana'a International Airport and the Shehein and Mukalla road checkpoints are of importance. These quarantine stations require increased staffing, 
inspector refresher training, disinfection equipment and installations (i.e. truck dip-races), animal holding areas, sampling kits, PPE and incinerators. Livestock smuggling takes place, mostly related to ruminants and is not greatly affecting poultry and poultry products.

\section{Relation between human and poultry pop- ulation.}

The commercial poultry industry profile (Table 2), defines the poultry and human population densities and number of poultry farms. Since the proximity of high-density poultry and human populations in the 9 governorates of Ibb, Taiz, Sana'a, Sa'adah, Amran, Dhamar, Al Baydah, Al Hudaydah and Al Dali must be considered at high risk. Their average poultry-human ratio (an indicator of potential human-infected poultry contact) is 3.5 chickens per human, nearly double the national average of 1.9. These 9 governorates contain virtually all (96\%), of the country's commercial poultry and $62 \%$ of the human population. The remaining 13 governorates are thinly populated with very little or no commercial or backyard poultry. Therefore, the designated 9 high-risk governorates listed, resources can be focused to maximum effect, and these governorates and their 220 districts containing the villages become the target areas for basic epidemiological principle in controlling infectious disease defines the source of infection as the basic infectious unit. This unit can be a household or farm, village, district or governorate, depending on the extent of the infection. The sooner the infection is identified, the smaller the epidemiological unit and the lower the cost and resources needed to contain the infection.

\section{Recommendations.}

1. Border security requires substantial upgrading of infrastructure, inspector training and enforcement of existing import regulations.
2. Private sector poultry industry organizations should be invited forthwith to join the MoAI Technical Committee for the disease infectious control, and have a voice in that body's decision-making process.

3. The Poultry Producers Organization should set up an Education Unit to provide much needed advisory services, including poultry farm biosecurity, to its members.

4. The municipalities responsible for poultry trading and processing should register all private poultry shop owners in their towns and cities, so that they can be accessed with government notifications, training and extension.

5. Extension messages should be designed specifically for the poultry traders to upgrade safe poultry handling and processing.

6. Government should pay closer attention to the veterinary manpower balance so as not to compromise the Service, by taking into account government hiring rates, attrition and the influx of new graduates.

7. Poultry farm biosecurity should be introduced by setting up demonstration farms in strategic locations to serve as learning centers for poultry producers.

8. Poultry farm biosecurity should comprise: perimeter fencing with entry gates for vehicles to deliver feed and water and to receive or dispatch poultry; disinfection footbaths at all farm building entries; building access limited to designated persons only; training of farm workers; change of clothing and footwear by farm workers; availability of disinfection sprayers and disinfectants; and sufficient rest time between production cycles.

Table (1): Poultry sector composition.

\begin{tabular}{|c|c|c|c|c|c|c|c|c|}
\hline \multirow{2}{*}{$\begin{array}{c}\text { Farm } \\
\text { Category }\end{array}$} & \multirow{2}{*}{$\begin{array}{c}\text { No. } \\
\text { Farms/ } \\
\text { Households }\end{array}$} & \multicolumn{2}{|r|}{ Parent } & \multicolumn{2}{|c|}{ Commercial } & \multicolumn{3}{|c|}{ Production Share \% } \\
\hline & & $\begin{array}{c}\text { Broiler } \\
\text { Stock }\end{array}$ & Layer Stock & Broilers & Layers & Eggs & DOC & Meat \\
\hline Sector 1 & 7 & $>50,000$ & & $>25,000$ & 200,000 to 450,000 & 30 & 65 & 10 \\
\hline Sector 2 & 25 & & 5,000 to 20,000 & $>10,000$ & 50,000 to 200,000 & 50 & 35 & 80 \\
\hline Sector 3 & Est. 3,000 & & & $<10,000$ & 5,000 to 50,000 & 20 & & 10 \\
\hline Sector 4 & 200,000 & & & \multicolumn{2}{|c|}{ Aver. 45/ household } & N/A & N/A & 3 \\
\hline Sector 1 - L & privately & & & Sector 2 & arge, privately-own & $\mathrm{rms}$ & & \\
\hline
\end{tabular}



Table (2): Overview of the Yemeni Poultry Subsector with Poultry / Human Ratio.

\begin{tabular}{|c|c|c|c|c|c|c|c|c|c|c|c|}
\hline \multirow[b]{2}{*}{ Governorate } & \multirow[b]{2}{*}{ Districts } & \multicolumn{2}{|c|}{ Parent } & \multicolumn{2}{|c|}{ Commercial } & \multirow[b]{2}{*}{$\begin{array}{c}\text { Total } \\
\text { Poultry }\end{array}$} & \multirow[b]{2}{*}{$\begin{array}{c}\text { Total } \\
\text { Farms }\end{array}$} & \multirow[b]{2}{*}{$\begin{array}{c}\% \text { Poul- } \\
\text { try }\end{array}$} & \multirow[b]{2}{*}{$\begin{array}{c}\% \\
\text { Farms }\end{array}$} & \multirow[b]{2}{*}{$\begin{array}{c}\text { Human } \\
\text { Population }\end{array}$} & \multirow{2}{*}{$\begin{array}{c}\text { Poultry } \\
/ \\
\text { Human } \\
\text { Ratio }\end{array}$} \\
\hline & & Layers & Broilers & Broilers & Layers & & & & & & \\
\hline Ibb & 20 & 39,201 & 147,005 & $3,848,233$ & $2,376,227$ & $6,410,666$ & 619 & 17.5 & 19.5 & $2,349,517$ & 2.7 \\
\hline Taiz & 23 & - & 373,638 & $5,099,907$ & 446,539 & $5,920,085$ & 500 & 16.2 & 15.8 & $2,524,199$ & 2.3 \\
\hline Sana'a & 16 & - & 245,009 & $4,420,807$ & 621,965 & $5,287,781$ & 450 & 14.4 & 14.2 & 964,872 & 5.5 \\
\hline Sada'a & 15 & - & - & $6,524,686$ & 39,870 & $6,564,555$ & 395 & 17.9 & 12.4 & 728,311 & 9.0 \\
\hline Emran & 20 & - & 294,010 & $1,053,537$ & $1,424,778$ & $2,772,326$ & 319 & 7.6 & 10.1 & 916,974 & 3.0 \\
\hline Dhamar & 12 & - & 252,998 & $2,344,331$ & 853,209 & $3,450,538$ & 343 & 9.4 & 10.8 & $1,407,027$ & 2.5 \\
\hline Al Biedah & 20 & 49,002 & 165,381 & $1,424,778$ & 526,278 & $2,165,439$ & 210 & 5.9 & 6.6 & 600,724 & 3.6 \\
\hline Al Hudieda & 26 & - & - & $1,478,041$ & 47,843 & $1,525,885$ & 117 & 4.2 & 3.7 & $2,270,799$ & 0.7 \\
\hline Al Dahl'a & & - & - & - & 972,045 & 972,045 & 67 & 2.7 & 2.1 & 494,277 & 2.0 \\
\hline Lahej & 15 & - & - & - & 582,096 & 582,096 & 73 & 1.6 & 2.3 & 764,018 & 0.8 \\
\hline Sana'a Cap. & 12 & 24,501 & 30,626 & 266,314 & - & 321,441 & 30 & 0.9 & 0.9 & $1,836,101$ & 0.2 \\
\hline Al Mahweet & 9 & - & 24,501 & 266,314 & - & 290,815 & 24 & 0.8 & 0.8 & 520,968 & 0.6 \\
\hline Abyan & 11 & - & - & - & 143,530 & 143,530 & 18 & 0.4 & 0.6 & 460,863 & 0.3 \\
\hline Marib & 14 & - & - & 39,947 & - & 39,947 & 3 & 0.1 & 0.1 & 253,926 & 0.2 \\
\hline Hajja & 31 & 19,601 & - & - & - & 19,601 & 4 & $0.1 \%$ & 0.1 & $1,555,867$ & 0.0 \\
\hline Al Goaf & 12 & - & - & 13,316 & - & 13,316 & 1 & 0.04 & 0.03 & 474,279 & 0.0 \\
\hline Reema /b & & - & - & - & - & - & & 0.0 & & 415,077 & 0.0 \\
\hline Shabwa & 17 & - & - & - & - & - & & 0.0 & & 490,525 & 0.0 \\
\hline Aden & 8 & - & - & - & - & - & & 0.0 & & 620,303 & 0.0 \\
\hline Hadramout & 30 & & & 125,000 & & 125,000 & & & & & \\
\hline \multirow[t]{2}{*}{ Al Mahera } & 9 & & & & & - & & & & & \\
\hline & 320 & 132,305 & $1,533,168$ & $26,905,211$ & $8,034,382$ & $36,605,065$ & 3,173 & $100.0 \%$ & 100.0 & $19,648,627$ & 1.9 \\
\hline
\end{tabular}

Table (3): Veterinary Manpower Resources versus Poultry Population.

\begin{tabular}{lccc}
\hline Year & $\mathbf{2 0 0 7}$ & $\mathbf{2 0 1 2}$ & $\mathbf{2 0 1 7}$ \\
\hline Veterinary manpower attrition & 230 & 180 & 130 \\
New veterinary graduates & 0 & 60 & 120 \\
Net manpower & 230 & 240 & 250 \\
Poultry industry growth & -- & $35 \%$ & $70 \%$ \\
Poultry population & $36.6 \mathrm{mln}$ & $49.4 \mathrm{mln}$ & $62.2 \mathrm{mln}$ \\
Vets per 1 mln poultry & 6.3 & 4.9 & 4.0 \\
\hline
\end{tabular}




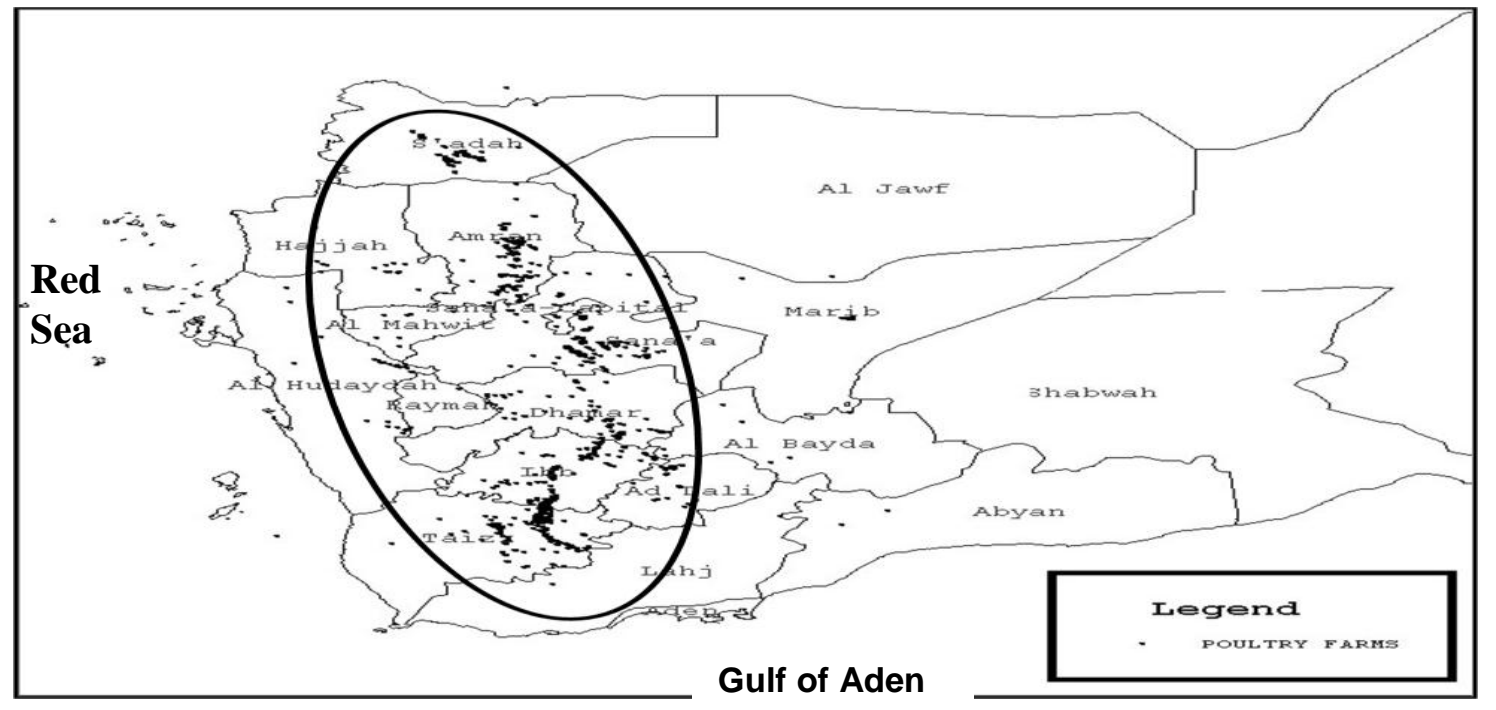

Fig. (1): The Poultry Industry and Commercial Poultry Farm Distribution.

From: USAID Yemen National Avian Influenza emergency Plan for Outbreak Response Preparedness (2006).

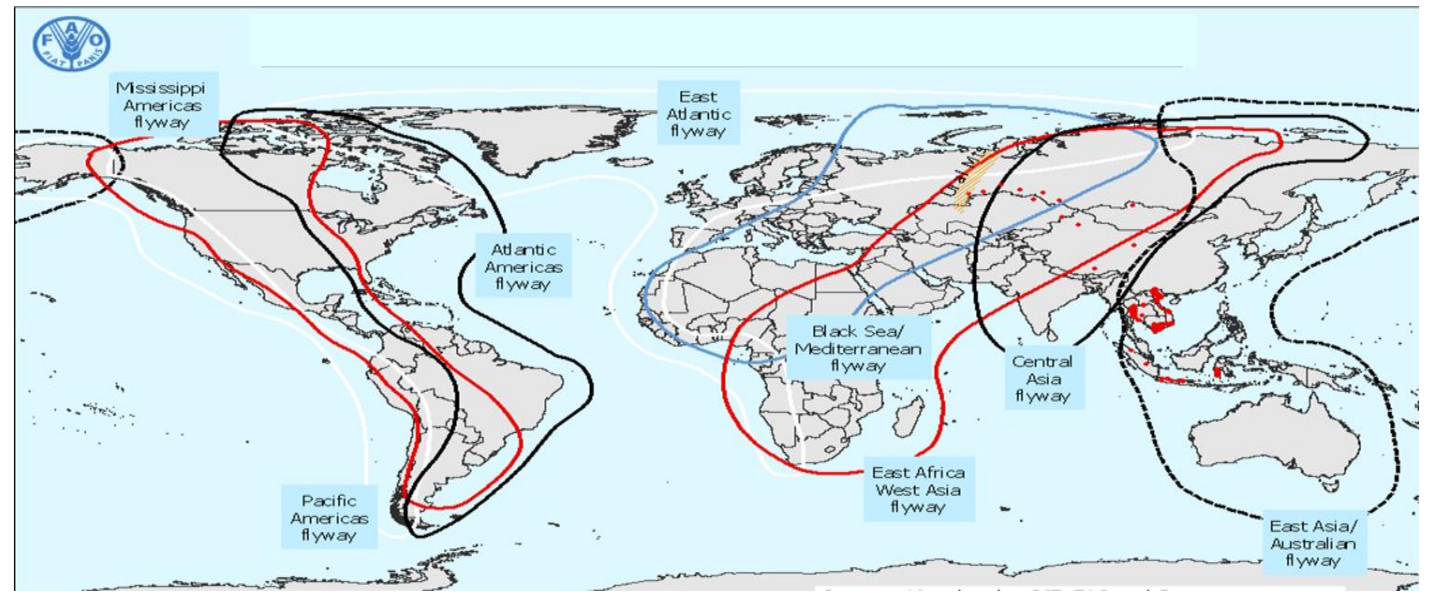

Fig (2): Major flyways of migratory birds.

\section{References}

1. Central Veterinary Laboratory (CVL).

2. Central Public Health Laboratory (CPHL).

3. Department of Animal Health (DAH).

4. Directorate General of Animal Resources (DGAR).

5. Directorate General of Agricultural Extension and Information (DGEI).

6. District Veterinary Centre (DVC).

7. CDC-created disease information database software (EPIINFO).

8. Food and Agriculture Organization of the United Nations (FAO).
9. Global Positioning System (GPS).

10. Ministry of Finance (MoF).

11. Ministry of Agriculture and Irrigation (MoAI).

12. Ministry of Public Health and Population (MoPHP).

13. National Centre for Health Education and Information (NCHEI).

14. National Canter for Surveillance and Disease Control (NCSDC).

15. World Organization for Animal Health (OIE).

16. Regional Veterinary Laboratory (RVL).

17. World Health Organization (WHO).

18. Yemen Veterinary Medical Association (YVMA) 